\title{
Seeding the world
}

\author{
Rafael Alvarez * \\ Baltimore, Maryland
}

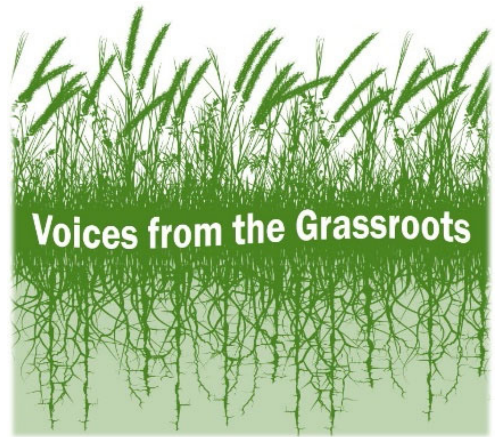

Submitted May 4, 2020 / Published online June 3, 2020

Citation: Alvarez, R. (2020). Seeding the world. Journal of Agriculture, Food Systems, and

Community Development, 9(4), 187-190. https://doi.org/10.5304/jafscd.2020.094.001

Copyright (C) 2020 by the Author. Published by the Lyson Center for Civic Agriculture and Food Systems. Open access under CC-BY license.

$\mathrm{D}$ ebra Williby-Walker has a great story to tell, and it's living under her roof in Mercer County, West Virginia. With her is eight-year-old Brady, her charismatic grandson, who has given away more than 6,000 packets of vegetable seeds to families around the world.

Williby-Walker, 52, and Brady live in Oakvale, population fewer than 125 , just a few miles west of a mountain range separating the Mountain State from far southern Virginia.

"Brady learned to plant seeds around the age of two or three from his Poppy, my Dad, who has two big gardens that connect to my property. One is just for potatoes, and the other? My mom cans

* Rafael Alvarez has been a working writer since he joined the city desk of the Baltimore Sun as a college student during the Carter Administration. He spent 20 years covering neighborhoods, crime, and blues music for the Sun before working on merchant ships and writing for the HBO drama, "The Wire." His many books include the short story collection Tales from the Holy Land and First and Forever: A History of the Archdiocese of Baltimore. He can be contacted at P.O. Box 432, Linthicum, MD 21090 USA or orlo.leini@gmail.com. More about his writing is athttps://patreon.com/rafaelalvarezbaltimore. everything they grow. They feed all of us in the family.

"Brady came to live with me when he was three, and at four, we started going everywhere together because I didn't have anybody to babysit. I've always done charity work-sending food to Ghana, stuff like that-and one day, we went to Heaven Sent Ministries, ${ }^{1}$ a Christian nonprofit in Princeton, West Virginia. There, we packed rice for children around the world.

"There were pictures of the hungry children who were going to get the rice and other nutrients. I believe it was there that he got the idea that if other kids and people learned to plant seeds, they can grow their own food and feed themselves.

"He was really inspired, so I said, 'If you want to do that, you have to do all the talking,' and so he began speaking to people about it. He calls it Sowing Seeds of Love. ${ }^{2}$ I put it on Facebook, and people began donating seeds.

"That's how it started," Debra said. Brady's idea was to help people grow food instead of simply receiving food from others. "Soon, he began collecting seeds here and in Canada, sending

\footnotetext{
${ }^{1}$ https://www.hsminc.org/

2 https://www.100daysinappalachia.com/2020/04/sowing-seeds-of-love-one-west-virginians-project-to-combat-hunger/
} 
more than 900 of them to a friend of mine named Ursula Candasamy in Uitenhage, South Africa, who died last October 2019. Ursula had a nonprofit called Heaven's Missing Angels. ${ }^{3}$

"Brady saw pictures of all the kids she was feeding at her soup kitchens and started sending seeds for tomatoes, carrots, lettuce, collards, all kinds of herbs, sage, and rosemary along with squash and cucumbers. Ursula grew the seeds in a greenhouse and then gave away the food.

"To pay for seeds and shipping, Brady recycles aluminum cans and has some litter pick-up jobs. He also has made a little extra money selling the book Ursula wrote about his Sowing Seeds of Love $^{4}$ project. People always ask if there are problems with sending seeds through the mail, and as of now, there haven't been any.

"Soon, people started contributing to Brady's work and made contacts with state agricultural agents in some counties near us, and they distributed seeds for him too. It's nice to have that kind of help, but Brady doesn't seem to care if anybody helps or not. He'll just do it himself. This March and April [2020] he's sent out 4,350 packets to counties all over West Virginia.

"It's common knowledge in our area through newspaper articles and TV that Brady collects garden seeds. Many people in Oakvale and the rest of Mercer County donate seeds. It sounds unbelievable, but folks in our neck of the woods have followed Brady and donated to his cause for four years now. This planting season, he will meet his goal of sowing seeds in all 55 West Virginia counties.

"So far, his grand total of seed packets sent out, including this planting season, is 6,650. When he sent seeds to a woman in Bedford, Pennsylvania, she took some of them and sent them to other parts

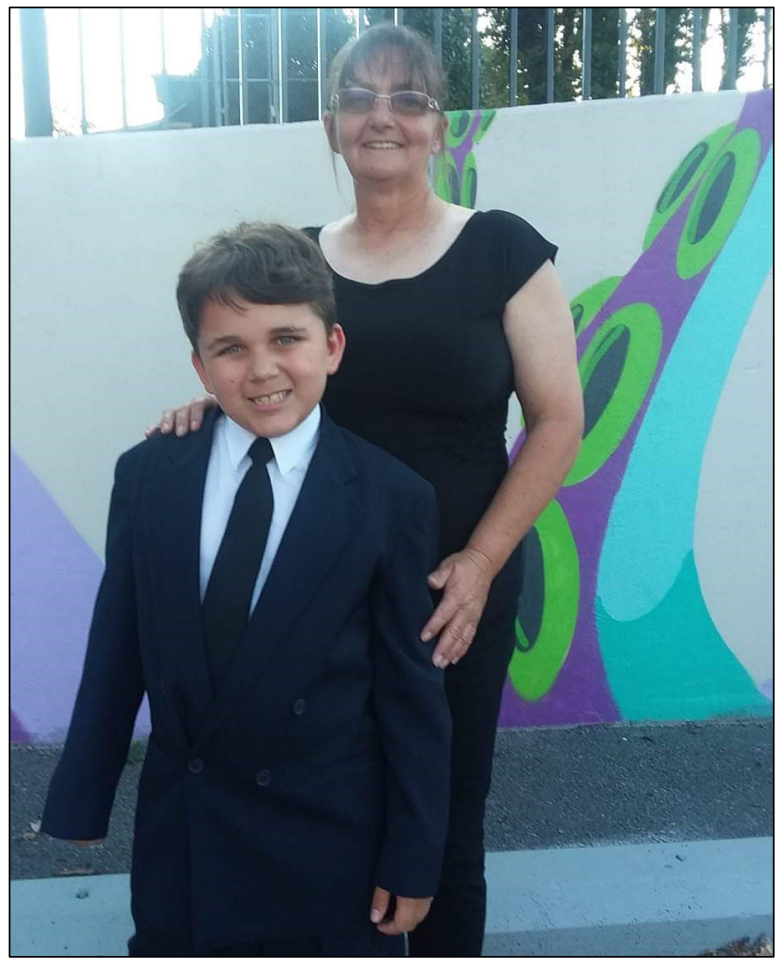

Brady Walker with his grandmother, Debra Williby-Walker. Photo courtesy of Debra Williby-Walker.

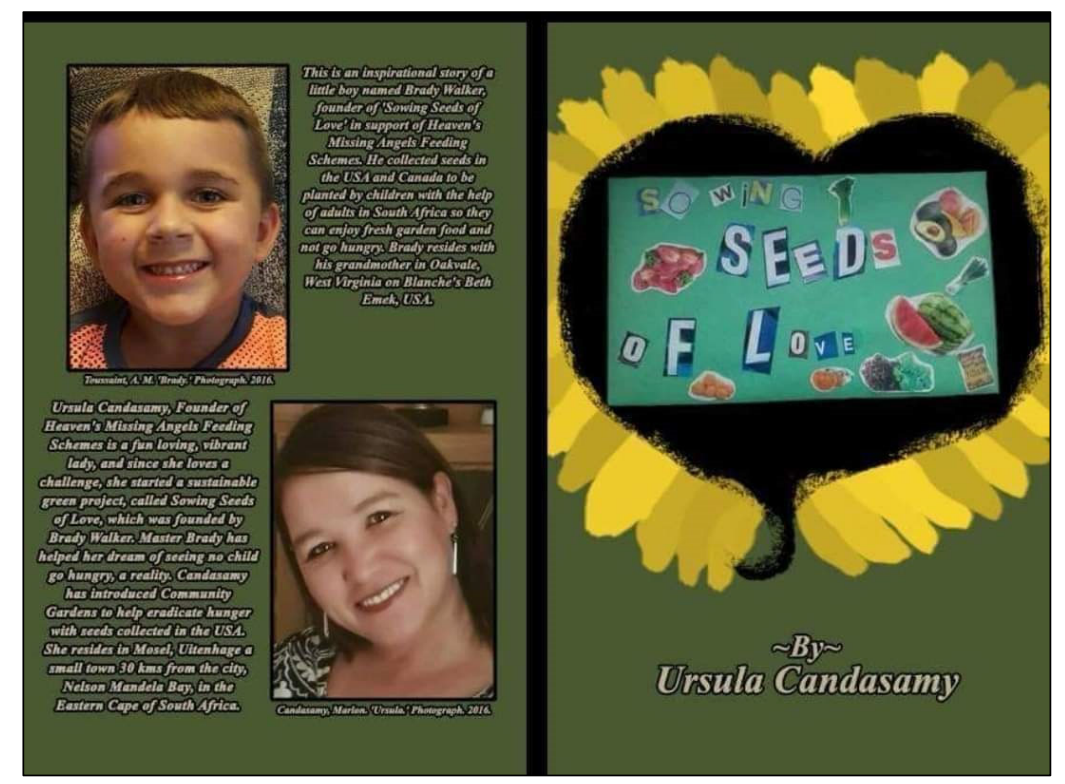

Ursula Candasamy of Uitenhage, South Africa, who passed away in 2019, ran a nonprofit called Heaven's Missing Angels. Sales of her book about the Sowing Seeds of Love project help fund the project's work. Photo courtesy of Debra Williby-Walker.

\footnotetext{
${ }^{3}$ https://www.latest.facebook.com/HarmonyForHope/posts/3433017316739679

${ }^{4}$ https://www.facebook.com/solhma/posts/ursula-candasamy-founder-heavens-missing-angels-proudly-displays-the-ton-ofseed/1799347407010175/
} 


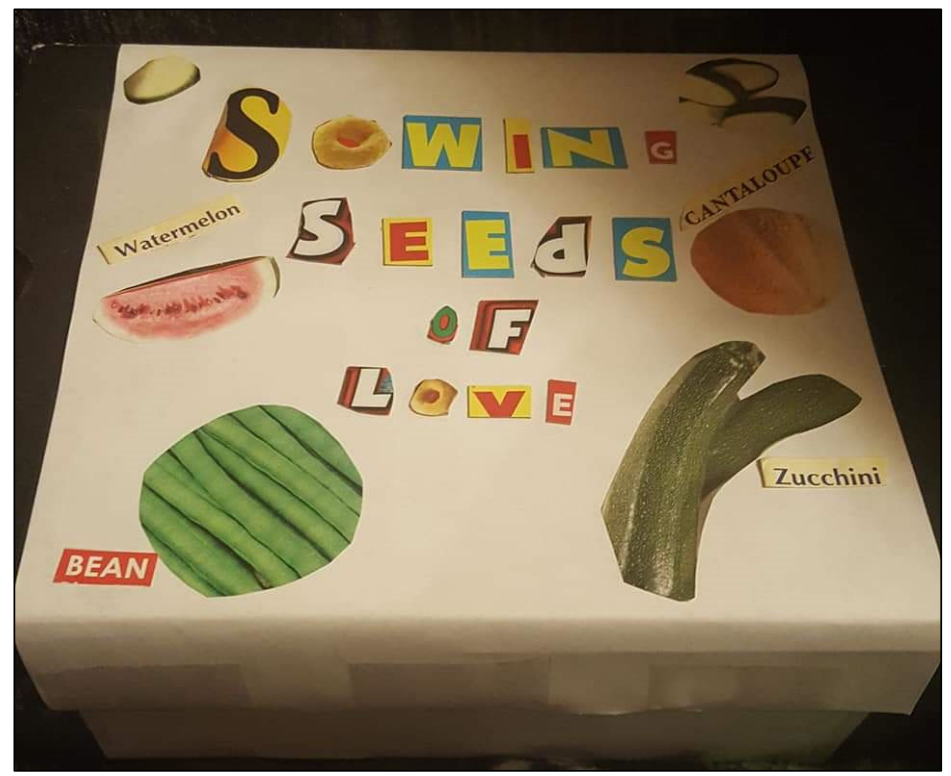

Members of the Create Your State Kids program have decorating shoeboxes to leave in various locations to allow the public to take as many seeds as they can use. Photo courtesy of Debra Williby-Walker.

of Pennsylvania, Detroit, and Maryland where people needed them.

"Even people in Canada have found out and donated. The brands are too numerous to name, and people send what they wish. The last shipment of donated seeds [were purchased from] High Mowing Organic Seeds ${ }^{5}$ in Wolcott, Vermont.

"It's his project, his idea," Debra said. “The only thing I do for him is post the stories on Facebook. [The recipients] send pictures of them planting when the seeds arrive, and then pictures of harvesting."

More than once, Brady has told his Marmee, "I can speak for myself; I know what I want to say." He takes the phone to answer the simplest, most beautiful of questions:

What's it like to see something grow?

"It's magical. I was watching strawberries grow when I was around four or five and then I ate them," said Brady, who turns nine on July 28, 2020, and is going into the fourth grade. "The kids we send the seeds to hardly have any stuff and we have all this stuff. We send our seeds to them because we already have so much. I feel proud of myself and it makes me happy to help them get what

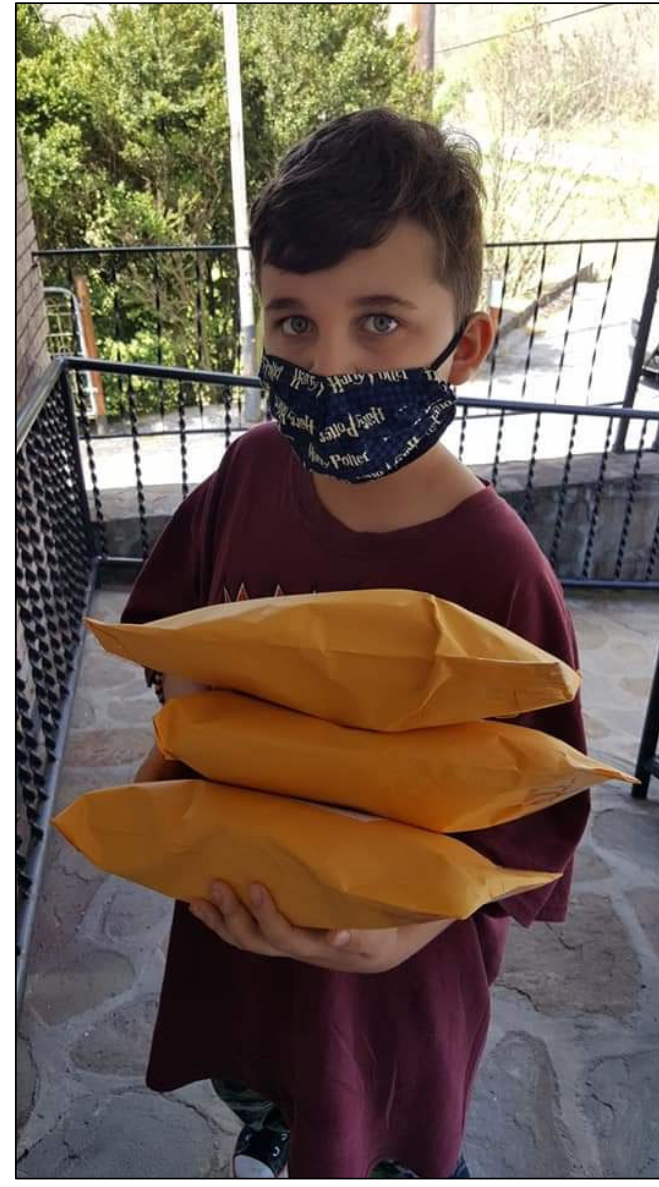

Brady Walker taking a shipment of donated seeds to the post office. Photo courtesy of Debra Williby-Walker.

they need."

Are you going to run a charitable nonprofit when you get older?

"I think I'll be a singer, actor, and artist who does charity work."

To that end, while continuing to collect and distribute seeds, Brady has been practicing singing like Tom Jones for an upcoming production of "Alice in Wonderland" in which he plays Humpty Dumpty.

As Brady gives the phone back to his grandmother, she says, "I don't think he really knows the magnitude of what he's done. Brady has fed thousands of kids with those seeds."

The COVID-19 global pandemic that has convulsed the world at the start of 2020 has not affected Brady's seed project, said his grandmother.

\footnotetext{
5 https://www.highmowingseeds.com/
} 
"We've had to make adjustments," she said, noting that the seed project continues to grow despite the spread of the virus. "His project has grown beyond us, and he was fortunate that he had the seeds before this pandemic really hit and people started scrambling to find seeds for themselves. They seem to be selling out of them since the virus hit.

"Because he had so many, he recruited kids from a program called Create Your State, ${ }^{6}$ mostly from the southern part of West Virginia. Brady and CYS founder Lori McKinney started Create Your
State Kids and began giving away seeds through that, too.

"The people he met through the Create Your State Kids project met for the first time last December and started decorating shoeboxes to leave here and there with a sign on the top of the box: 'Take what you wish...'

"They were supposed to get back together this past March but, you know, it had to be cancelled. Right now, they're thinking about a virtual gathering and hope they can meet in person later in the year."

${ }^{6}$ https://createyourstate.org/home 